\title{
Components of Drama Therapy in Family: New Approach to Solve Marital Conflicts
}

\author{
Sayedehmaryam Farhangsafavi ${ }^{1 *}$, Seyed Mohammad Kalantarkousheh ${ }^{2}$, \\ Abdolah Shafiabadi ${ }^{3}$
}

\section{ABSTRACT}

Nowadays, researchers and family therapists, using all of the facilities, hypothesizes, and methods, aim to solve marital and family conflicts. Drama therapy can be deemed as a significant method for this purpose. In the present research some pivotal components of Drama therapy such as, creativity, spontaneity, encounter, here and now are deeply considered. The results indicated that the aforementioned factors are of pivotal role to widely solve marital conflicts. Lastly, it is undeniable that drama therapy and family therapy are hand in hand.

Keywords: Drama Therapy, Marital Conflicts, Couple Cooperation, Problem Solving

Art, in many years, has been resorting to help human being in different situations. Further, therapists have tried to use different and creative techniques for healing. One of the artistic methods in healing is the use of theater that conducted by Jacob Moreno. Indeed, show and theater make fun in person as well as create the sense of happiness, sadness, and in the upper level the sense of identification. Drama therapy is used in approaching the goals like, increasing the quality and enriching the close relationships, emotional intelligence, asserting, and conflict resolution in big and small groups including family. In other words, family is a small group, formed of people who have profound warm relationship and they could utilize the features of drama therapy for improving and modifying their relationships; because with the enriching in the mentioned cases, they could improve the quality of their lives. The use of drama therapy, its components, and the marital conflict resolution will be discussed in the present review article.

\footnotetext{
${ }^{1}$ Master in Family Counseling, Department of Counseling, Faculty of Psychology and Education Sciences, Allameh Tabataba'i University, Iran

${ }^{2}$ Assistant Professor, Department of Counseling, Faculty of psychology and Education, Allameh Tabataba'i University, Tehran, Iran

${ }^{3}$ Professor, Department of Counseling, Faculty of psychology and Education, Allameh Tabataba'i University, Tehran, Iran

*Responding Author

(C) 2016 I S Farhangsafavi, S Kalantarkousheh, A Shafiabadi; licensee IJIP. This is an Open Access Research distributed under the terms of the Creative Commons Attribution License (http://creativecommons.org/licenses/by/2.0), which permits unrestricted use, distribution, and reproduction in any Medium, provided the original work is properly cited.
} 


\section{What is the drama therapy?}

Drama therapy is the way to review the obstacles through the live performance of referred persons' lives events and finding the solution with the help of theatrical metaphors. The referred persons tussle with their difficulties, grappling with squabbles, for achieving the right solution they initiate instead of just speaking, and the interpersonal problematic status of the referred persons will be reconstructed to been settled down by individual through raising the awareness, that is, the late critical and harmful situation will be shown in here time and a solution will been looked for (Dugan 2010). This is Drama therapy which is a way of life without forcing to be punished by events and also is an unfinished emotion of the past (Holms \& Watson 2005).

Drama therapy is a form of therapeutic in which the members should not wait and speak about their lives but the life actively and enacting will be come in to the group and the members by using the artistic techniques are involved in their difficulties with the help of each other (Holms 2014). Factors such as drama externalizing, drama sympathizing, psychic playing and art directing and transformation are the examples that causes heal in drama therapy (Jones 2008).

\section{Components of Drama Therapy}

From Moreno's point of view, the concept and the creation of the drama therapy was with occupied humanity components including, creativity, spontaneity, encounter here and now and encounter (Davis 2014). The components which are crucial and depend on each other as the other components are incomprehensible if the one is not been comprehended. In the table 1 the chief components are brought and are discussed.

Table.1. Components of Drama Therapy

\begin{tabular}{|l|l|l|}
\hline Components & Meaning & Usage \\
\hline Creativity & Producing new experience & $\begin{array}{l}\text { Solving problem and creation } \\
\text { new idea }\end{array}$ \\
\hline Encounter & $\begin{array}{l}\text { Showing the sufficient } \\
\text { reaction to a new thought, or a } \\
\text { new reaction to an old crisis }\end{array}$ & Achieving to encounter \\
\hline Here and now & $\begin{array}{l}\text { A relation full of excitement, } \\
\text { companying } \\
\text { between healer, patient and } \\
\text { the healing goals }\end{array}$ & $\begin{array}{l}\text { The main factor of healing } \\
\text { moment }\end{array}$ \\
\hline Encounter & $\begin{array}{l}\text { Feeling again the spectrum felt } \\
\text { excitements in crisis situation }\end{array}$ & $\begin{array}{l}\text { Deep healing and the sense of } \\
\text { peace }\end{array}$ \\
\hline
\end{tabular}

Creativity in drama therapy is one the most essential components. Creativity means that, what is produced during an experience with no pre pattern before performing, or preplanning carefully (Koory2012). It is believed that each person will be in a good situation of creativity and tussling 


\section{Components of Drama Therapy in Family: New Approach to Solve Marital Conflicts}

his problem by participating in drama therapy (Tomean Moreno, Blonquist, Ratzel 2000). Spontaneity is the next chief part in drama therapy. Spontaneity means showing the adequate reaction (and not satisfactory) to a new thought, or showing a new reaction to an old crisis (Koori 2012, Carp 2005). Creativity and spontaneity are the same in a way that there is never creativity without spontaneity. Offering the creativity, spontaneity helps to every new born baby in his birth moment to be ready against the life. The process of the mutual relation between creativity and spontaneity is an ongoing sequence, helping person to develop in his life (Moreno 1987). Encounter regarded as main factor for healing. Encounter is an excitement relation between healer, patient, and healing goals along with discussion that affords the healing encountering between patient and the healer, touching each other, physical dealing of members, confronting and even fighting and perception of each other (Moreno 1987).

Here and now is a very significant component, having close relation with the creativity and spontaneity. In drama therapy, person instead of telling an events with past - tense patterned sentences and verbs he starts playing his adventure in the present time and shows what would he do if his appropriate crisis "at this moment" happens. The motto of drama therapy is that if it tells to its member: "do not tell us your problem, so show it to us". The performance allows to the main role keeper to show his problem at first, then to show the effects, received of the problem or his crisis, then with different technique he reacts to the appropriate situation and feels a type of mental encounter.

catharsis is the special emotional status, such as mourning, fear, enmity, happiness, sin, feel to be guilty, ennui and excitement; that usually the main role experiences after reconstruction and performing his problematic situations in his life again (Blunter 2000). This situation is visible when person takes off his mask. For instance, when someone plays his role as Oedipus, what kind of feeling about the story he may has under his mask whenever his mask is took off? And what is going on? Now what is going on the main role in the scene of drama therapy? Is it feeling of fear, enjoying, happiness or anger? Moreno recognizes these status and emotions as aesthetic catharsis which emerge during playing role by the main role player. Moreno's discovery caused a revolution in theater. A few people know indeed that every individual under the mask as player, realizes himself and plays a feature of himself spontaneity (Tomean, Moreno, Blumquist and Rotzel 2000). Now, this kind of catharsis is come to healing realm. For Moreno, the made mental catharsis originated of encounter in the present time that is resulted of creativity and spontaneity results in profound healing and the deep scenes of relaxation in person (Moreno 1987); because it seems that this component causes that the main role player (and even audiences) with playing an old role of themselves or their next of keens; release from stress and anxiety of an old and problematic - stressful event.

\section{Marital Conflict}

Marriage is the base of the family, constructing the most important and the most basic human relationship (Ezden, Celen, 2014). Definitely, accuracy or any disorder in this unit results in the 
stability or in the failure of the society's pillars (Zarnaghash - Shahni 2013). There is a complex collection of relations (Setir 1972) so in every marriage marital conflicts are unavoidable (MC Quiz, Davis, Comings 2009, Olson, Sig, Larson 2012). The capability of the couples in the marital for controlling their disputes and conflicts are resulted in better relations and then in their wellbeing. Marital conflict will be the cause of mental stress and excitement, depression, psychological problems, and will be the cause of the deficiency in the children education and the father - child relation; it also increases the rate of their mental stress and social incompatibility (Faircloth, Schermerhorn, Mitchell, Cummings, and Cummings 2011). Marital conflict is unavoidable and exists in any family, however, it does not make disorder in family inherently. In other words, there are two kind of marital conflict, namely "useful" and "destructive" ones. Managing the conflict despite of frequency of occurrence and its violence has more weight. If the couple could control their conflicts in a logic manner; speaking, not using the verbal and physical violence, the useful conflict can be take place. There is no doubt that self-confidence and feeling of security of children can be fed by constructive conflict. On the other hand, when the conflict will be through the violence, angriness, and parents' warlike decisions like physical and verbal violence, threat and insolence to persons, so it is called as destructive one (MC Koi, Cummings, Davis 2009).

\section{Reasons of Marital Conflicts}

In the family in which the marital system is disturbed, the most conflicts are visible. When a couple is incapable to solve their problems so they cannot manage the children's subsystem's problems as a result the system of parenting will be disturbed either (Barker or Chenge 2013). It seems that the most chaos situation is visible in the family, having relationship problem couples. According to Setir (1972) a confused family has at least one of the following situations: may the environment of the family be frustrated as impatience is obvious, or all of the events are too fast and there is no balance in the family atmosphere. In other form, the atmosphere is calm as the calmness of a moment before thunder, ready for war, and any moment there is a possibility of a quarrel or a fight at home. Sometimes the environment is stealthy as in the spy movies, and family member are distrust to each other, seeking and escaping all the time. The common feature of such families is that apparently the family unity is a kind of duty and members just try to tolerate each other.

\section{The Realm of Marital Conflicts and Drama Therapy}

The marital conflicts may have been done in six dimension: marital cooperation, sexual relationship, financial subjects, emotional reaction, children support, personal communication with relatives and communication with spouse's relatives (Sanai Zaker 1387), which is shown in the following chart. 
Table.2. Realm of Marital Conflict

\begin{tabular}{|c|c|c|c|}
\hline $\begin{array}{l}\text { Realm of marital } \\
\text { conflicts }\end{array}$ & Definition & Symbol of conflict & $\begin{array}{l}\text { The result in the } \\
\text { matrimony }\end{array}$ \\
\hline Marital cooperation & $\begin{array}{l}\text { Partnership in } \\
\text { activities like sexual } \\
\text { relationships, } \\
\text { parenting and so on } \\
\text { and so forth }\end{array}$ & $\begin{array}{ll}\text { Reduction } & \text { of } \\
\text { satisfaction } & \text { of } \\
\text { matrimony } & \end{array}$ & $\begin{array}{l}\text { Increase of the } \\
\text { conflicts }\end{array}$ \\
\hline Sexual relationships & $\begin{array}{l}\text { Reduction in the } \\
\text { quantity or in the } \\
\text { quality of the sexual } \\
\text { relations in which } \\
\text { couple find no } \\
\text { excitement in sex }\end{array}$ & $\begin{array}{l}\text { Emotional } \\
\text { manometer of the } \\
\text { couples }\end{array}$ & $\begin{array}{l}\text { Cause of the } \\
\text { interaction with the } \\
\text { confused relations of } \\
\text { the couples }\end{array}$ \\
\hline Emotional reaction & $\begin{array}{l}\text { Expressing the } \\
\text { uncontrolled negative } \\
\text { emotions by couples }\end{array}$ & $\begin{array}{l}\text { The calm before the } \\
\text { storm }\end{array}$ & $\begin{array}{l}\text { Negative continues } \\
\text { actions and reactions } \\
\text { of the couple }\end{array}$ \\
\hline \multirow[t]{2}{*}{ Children support } & Children support for & $\begin{array}{l}\text { Entrenchment against } \\
\text { each other }\end{array}$ & $\begin{array}{l}\text { Parents' antithetical } \\
\text { rules }\end{array}$ \\
\hline & $\begin{array}{l}\text { Entrenchment against } \\
\text { partner }\end{array}$ & & To educating children \\
\hline $\begin{array}{l}\text { Family relation with } \\
\text { relatives }\end{array}$ & $\begin{array}{l}\text { Continuing the } \\
\text { relation with friends } \\
\text { and source family of } \\
\text { partner }\end{array}$ & $\begin{array}{l}\text { Being the source } \\
\text { family or friends as a } \\
\text { first priority than } \\
\text { partner and children }\end{array}$ & $\begin{array}{l}\text { Feeling of having low } \\
\text { importance in one of } \\
\text { the couples }\end{array}$ \\
\hline Financial subjects & $\begin{array}{l}\text { Financial subjects is } \\
\text { the meaning of power } \\
\text { influence and power } \\
\text { balance in the family } \\
\text { inexplicitly }\end{array}$ & Power struggling & $\begin{array}{l}\text { Creation of being } \\
\text { controlled in one of } \\
\text { the couples }\end{array}$ \\
\hline
\end{tabular}

Marital cooperation: as mentioned in table2, couples have lots of ordinary activities, Including, sexual relations, parenting, relation with partner's family, doing housework and fulfilling the partner's demands, paying attention to each other, and affording to achieve to common aims. Marital cooperation also includes the wide range of cooperating in works such as housekeeping, having meal with each other, shopping, up to social protection of each other, and at last creation the better mutual understanding of each other's feelings. Cooperation among spouses for their relation improvement is fundamental during their personal and family lives. Moreover, cooperating behave is known as a main element of making a successful relation that is caused satisfaction increasing of matrimony and it increases the couples' intimacy level (Leget, Roberts, Pitman, Bizak, and Mors, 2012). 


\section{Components of Drama Therapy in Family: New Approach to Solve Marital Conflicts}

It is told that one of the most important drama theater components however, is encountering, including mutual involvement of members. This feature can be used in family therapy, that is, family members are put in the performance position by director; family members are encountered with problems and each other, so they could release of inchoate emotions, nonsolvable conflicts and inchoate issues.

Sexual relations acts as an emotional monometer and marital conflict level reflector. Indeed, sexual life is the depth of the marital relations and its problems indicate the hidden and suppressed problems and worries of the difficulties (Olson, sig, Larson, 2012).

Most of the married men worry about unpleasant sexual relations, so they decrease the frequency of their sexual activities. On the other hand, to make low pressure to their husbands, women try to be inactive and have less expectation and then the rate of couples' sexual activities falls down. Couples do not talk to each other and become silent about what is happening during this process. Couples stuck in a method of facing with sexual matters and they shut any way. Withdrawing of having sex, couples ignore their problems (Glaser 2010).

Drama therapy could be practical to solve the conflicts of this area. Instead of being silent, couples face with and speak about difficulties in here and now, and they use creative solutions instead of being silent to make a sexual relations, eventually by using spontaneity, marked as humanitarian feature, utilizing of drama therapy advantages, they achieve the mental encounter and experience the creative - spontaneity.

Emotion is the mean of motivation or confusion of mind, feeling, affection, and excitement and also it's a factor of compromise and making a human relation with nature. Containing the wide range of depression, disease (increasing the eternal negative emotions), drug misuse, and severe mental illness, emotional reactions have various forms (Scoble, Roth, Merag, Ship, Dittos, Ezlamak, Shutter, 2012). It seems that it increases the conflicts and causes the destruction of common relation between them if emotional reaction will be increased among couples.

Catharsis which is categorized as drama therapy's main components are seemed could help couples to experience the range of visible emotions during crisis. Nevertheless, in this time he faces them with appropriate techniques. They release of unfinished and negative feelings which they may have against their partner's family with the use of catharsis.

Children support: parents in families without any marital conflict are as the family's leaders, knowing their duty to teach children the humanity (Setir 1972); however children aggressiveness, sentiment exhaustion, and incompatibility are the result of destructive marital conflict of a family (Pop, Comings, and Gock - Moray, 2002). As a matter of fact, marital conflict would effect on children's behavior. Children would be under effect of negative effects of conflicts if parents cannot use conflict as a learning factor of new behaviors for their children 


\section{Components of Drama Therapy in Family: New Approach to Solve Marital Conflicts}

(MC quiz, Comings, Davis, 2009). It seems that there is a need for achieving new solutions and producing rich experiences for parents. Creativity is on of main humans' features that drama therapist tries to wake them up among participants. Additionally, drama therapist can lead family members to catharsis with encountering and involving them in difficulties and to force them to scrimmage with problems.

Increasing personal communication with relatives and communication with spouse relatives: each of the couple should make contacts with the other family members and friends during their spousal life. Couples spend a short period of time during a week before marriage; every of them claims that the other part is very important and others have less importance; but after a while, job, family and friends get more importance than other part and one or both of parties may feel to compete with these persons (Setir 1972). With using of drama therapy components, couples could been put in conditions in which they face with their old difficulties about making contact with each other's family and friends to attain mental encounter . Unfinished emotions will be settled down, those in family relations could create causes of harassments and unwillingness to make relations and couples would receive calmness, releasing from these emotions.

Financial subjects: financial matters are something more than a talking about money and budget. Financial matters implicitly are the mean of power influence in family and also power division (Olson, Sig, Larson, 2012). Social financial problems lead to family financial problems and consequently effect on marital conflicts (James, Wilson, 2002). Financial issues are not the origin of marital conflicts but most of the family arguments are related to money. Children learn in families that everyone who possesses money has power. Paying attention will be shown when money is received and money will blocked if child sulks or becomes angry. Money occupies emotions dignity indeed. Problems will increase while one or both spouses thinks about money

and neglects of making relation, or when one tries to control other partner through financial issues or tries to enforce them (Good,2001).

Accordingly, financial issues and its difficulties could banish couples from each other and dim the relation between them, but it seems utilizing of creativity components for settling financial issues down and also here and now component for facing with financial problems and making solution can be effective in this realm of conflict; according to current family situation in society. To solve their financial conflict, couples are requested to face with each other and to talk about the depth of their dissatisfaction of being under control or under influence. For that reason, it is expected they reach to mental encounter and to the balance of power in family, which is the main goal of healing.

\section{Drama Therapy and Resolution of Family Conflicts}

To turn destructive marital conflicts to constructive one, various solutions could be chosen. Drama therapy could create selected area by a family to settle conflicts down. For this action, drama therapist may invite family to show their permanent arguments in healing session. The 
selected part of conflict, chosen by family during drama therapy is very important and it indicates their important conflicts between them. So these scenes should carefully have been shown and all details must have been paid attention to. In this research, researchers got with involving family members in drama therapy, the relation between members and children with parents would be better and a new idea about drama therapy will family members will have (Tar Niger, Fin, Aston, Gentry, Billy, Parton, and Fisher, 2008).

For Tomean Moreno (2013) no performance on the stage has any limitation and stage performance is a new discovery of reality. Thus it can be regarded that drama therapy could be a proper scene to perform family shows and marital conflicts. Schetgeny (cited in Marsino, 2002) believes that it's better to take seat the entire family member circular and made space among them been chose for play. In this form, all members can see each other's face so their reactions are watched by them. This space is a magical, sacred, and safe for members that without any damage they could perform themselves.

It appears that this magical atmosphere could offer an opportunity for family to grapple with their problems and instead of giving up, being passivity it could gallop to realms of marital conflict through creativity, creating new solutions, and to have a sight to problems from a new window. Finally, family's conception of involvements could change destructive conflicts to useful ones and could reinforcement the family system and make it independence.

Drama therapy as a healing process is a way which helps participants to recreate their mental and psychological problems in a real system, instead of just speaking. In other word, members, in this method though performing their problems and conflicts that could be marital conflicts, recent events, fears, and their wishes; brings them to present time to settle them all down. The healer can force conflicted couples to take a creative look at their problems, to face with their conflicts, to be spontaneity, and to face with an old crisis use a new method, to settle their crisis down in here and now, and to achieve mental encounter, utilizing of drama therapy components.

\section{CONCLUSION}

Drama therapy is a practical work inherently, mental encounter, and ending of unfinished emotions are the results of its practical feature. These features could be used in involvements, marital conflicts, and with healing of old wounds in couples' relation it would been put ointment on their wounds. Drama therapy components in marital conflicts resolution are shown in table 3: 
Table3.Components of Drama Therapy and Marital Conflicts

\begin{tabular}{|c|c|c|}
\hline Marital conflicts & Drama therapy components & The desired result \\
\hline Marital cooperation & Encounter & $\begin{array}{l}\text { Finished the unfinished } \\
\text { emotions, } \\
\text { emotions, and half - finished } \\
\text { issues }\end{array}$ \\
\hline Sexual relations & $\begin{array}{l}\text { Here and now, creativity, and } \\
\text { spontaneity }\end{array}$ & Encounter \\
\hline Emotional reaction & Encounter & $\begin{array}{l}\text { Re-experiencing the negative } \\
\text { feelings, and settling down, } \\
\text { and terminating to unfinished } \\
\text { emotions against spouse }\end{array}$ \\
\hline Children support & Creativity and encounter & $\begin{array}{l}\text { Direct involvement with } \\
\text { problems and finally healing } \\
\text { and encounter }\end{array}$ \\
\hline $\begin{array}{l}\text { Personal communication with } \\
\text { relatives and friends }\end{array}$ & Encounter and encounter & $\begin{array}{l}\text { Releasing of unfinished and } \\
\text { negative feelings against } \\
\text { relatives and friends }\end{array}$ \\
\hline Financial subjects & $\begin{array}{l}\text { Creativity, encounter , and } \\
\text { here and now }\end{array}$ & Balancing in power \\
\hline
\end{tabular}

As it is observed in table 3, needing to marital conflicts reduction, improving the couple's relations, best using of useful conflict, needing education and healing intervention to prevention, healing and re- empowering the family are completely obvious. One of the suggested treatment solutions is drama therapy; it will be expected to offer a new way in family therapy according to the steps, used in this therapy.

The achieved results are equal with Belil's research (2011). He indicated that drama therapy is positive for women mental disorders reduction and also for reduction of depression rate. The results would be declared that drama therapy and its components effect on mental health and depression reduction (as we saw in the realm of marital conflicts in reduction of emotional reaction).

And also achieved results are equal with Dugan's (2010) researches, believing in the effectiveness of drama therapy on those, suffering of anxiouslambivalent attachment, and it causes in self-acknowledgement increase, insight improvement, attachment styles acknowledgement in relative attachments and future attachment, self-confident creation, and sympathy skills creation. Attachment is effected on marital relations and conflicts and it could be declared that drama therapy components could be used in improvement of marital problems realm. 


\section{Components of Drama Therapy in Family: New Approach to Solve Marital Conflicts}

Gatta, and colleagues (2010) believe that drama therapy helps in severe mental disorder treatment. This result could be declared for better couples' relation and the prevention of severe mental and physical disorder.

Tar Niger and others (2008) concluded that with involving and encountering family members in the safe atmosphere of drama therapy, leading them to solving the problem and with experiencing new feelings family therapy is eminent. These results are equal with the results of this research. This result declares that drama therapy is a new gate to marital conflicts resolution and also is to destructive conflict to useful conflict exchange.

Generally it seems that drama therapy and its components have effective usage in family, and it could solve the marital conflicts in its various realms. Main components of drama therapy including, creativity, spontaneity, encounter, here and now, and encounter are the especial humankind's features; that humankind gradually recedes them through improvement in his life, however drama therapy seeks to use these especial features to solve the problems creatively through re- strengthen them; and these features could be imported in different realm, specifically family squabbles.

\section{REFERENCES}

Barker, P., \& Chang, J. (2013). Basic family therapy. John Wiley \& Sons.

Belil, Ebrahimi. (2011). The effects of psychodrama on depression and mental state among women with cronic mental disorder. European Psychiatry, (26), 621, 2-26.

Blatner, Adam. (2000). Foundation of psychodrama. New York: springer.

Blatner, Adam. (2003). Psychodrama. Schaefer, Charles (Eds), Play Therapy with Adults (3461). New Jersy: John Wiley and Sons.

Corey, Jerald. (2012). Theory and practice of group cousneling. Boston: Cengage Learning.

Davies, M. H. (2014). Dramatherapy and psychodrama. Dramatherapy: Theory and Practice 1, 104.

Dogan, Turkan. (2012). The Effects of psychodrama on young adults' attachment styles.The Art in Psychotherapy, 37, 112-119.

Faircloth, W.Brad, \& Schermernhorn, C. Alice, \& Mitchell, M. Patricia, \& Cummings, S. Jennifer, \& Cummings, E. Mark. (2011). Testing the long-term efficacy of a prevention program for improving marital conflict. Journal of applied developmental psychology, (32), 189-197.

Gatta, Michela, \& Lara, Dal Zotto, \& Lara, Del Col, \& Andrea, Spoto, \& Paolo, Testa Costantino, \& Giovanni, Ceranto, \& Rosaria, Sorgato, \& Carolina, Bonafede, \& PierAntonio, Battistella. (2010). Analytical psychodrama with adolescents suffering from psycho-behavioral disorder: short term effects on psychiatric symptoms. The Arts in Psychotherapy, 37, 240-247.

Glasser, W., \& Glasser, C. (2010). Getting together and staying together: Solving the mystery of marriage. Harper Collins.

Good, N. (1987). How to love a difficult man. Sheldon Press.

Holmes, Paul. (2014). The inner world outside: object relations theory and psychodrama. London and New York: Routledge. 


\section{Components of Drama Therapy in Family: New Approach to Solve Marital Conflicts}

James, Adrian L, \& Wilson, Kate. (2002). Couple, conflict, and change: social work with marital relationships. London and New York: Tavistock Publications.

Jones, phil. (2008). Research into core processes of drama therapy: Vigenettes and conversations. The arts in psychotherapy, 35, 271-279.

Karp, Marcia, \& Holmes, Paul, \& Watson, Michael. (2005). The handbook of psychodrama. London and New York: Routledge.

Leggett, Debra G, \& Roberts-Pittman, Bridget, \& Byczek, Sara, \& Morse, David T. (2012). Cooperation, conflict, and marital satisfaction: Bridging theory, research, and practice. The Journal of Individual Psychology 68, (2), 78713-7819.

McCoy, Kathleen, \& Cummings, E.Mark, \& Davis, Patrick T. (2009). Constructive and destructive marital conflict, emotional security and children's prosocial behaviour. Child Psychol Psychiatry. 50, (3), 270-279.

Moreno, Jacob. (1987). The Essential Moreno: Writings on psychodrama, group method, and spontaneity. New York: Springer Publications Company.

Olson, David, \& Olson-Sigg, Amy, \& Larson, Peter. (2012). The Couple Checkup: Find Your Relationship Strengths. Tennessee: Thomas Nelson Inc.

Ozden, Melis Seray, \& Celen, Nermin. (2014). The relationship between inherent and acquired charactereistics of human development with marital adjustment. Procedia, (48) , 48-56.

Papp, Lauren, M, \& Cummings, E Mark, \& Goeke-Morey, Marcie C. (2002). Marital conflicts in the home when children are present versus absent. Developmental psychology, 38, (5), 774-783.

Satir, Virginia. (1972). Peoplemaking. London: Souvenir Press Ltd.

Scategni, Wilma. (2002). Psychodrama, group processes, and dreams: Archetypal images of individualation. (Vincent Marsicanio, Trans,). New York: Taylor and Francis. (Original work published 1996).

Schewble, David C, \& Roth, David L, \& Elliott, Marc N, \& Chien, Alyna T, \& Mrug, Sylvie, \& Shipp, Eva, \& Dittus, Patricia, \& Zlomke, Kimberly, \& Schuster, Mark A. (2012). Marital conflict and fifth-graders'risk for injury. Accident Analysis and Prevention, 47, 30-35.

Tharinger, Deborah J, \& Finn, Stephen E, \& Austin, Cynthia A, \& Gentry, Lauren B, \& Bailey, Karen Elaine, \& Parton, Victoria T, \& Fisher, Melissa E. (2008). Family sessions as part of child psychological assessment: Goals, Techniques, clinical utility, and therapeutic value. Journal of Personal Assessment, 90, (6), 547-558.

Toeman Moreno, Zekra, \& Blomkvist, Leif Dag, \& Rutzel, Thomas. (2000). Psychodrama, surplus reality and the art of healing. UK: Psychology Press.

Toeman Moreno, Zerka. (2013). The Quintessential Zerka: on psychodrama, sociometry andgroup psychptherapy. London and New York: Routledge.

Zarnaghsh, Maryam, \& Zarnaghsh, Mina, \& Shahni, Razieh. (2013). The influence of family therapy on marital conflicts. Procedia-Social and behavioral science, (84), 1838-1844.

How to cite this article: S Farhangsafavi, S Kalantarkousheh, A Shafiabadi (2016), Components of Drama Therapy in Family: New Approach to Solve Marital Conflicts, International Journal of Indian Psychology, Volume 3, Issue 3, No. 7, DIP: 18.01.119/20160303, ISBN: 978-1-36512175-3 